ずれも $\theta=\tan ^{-1}(2 / 5)=21^{\circ} 48^{\prime}$ である。 第 5 図は電極配置は OCPP で, $a=2$ 亿 ついて $n=1,2,3,4,5,6$ およひ 8 としたときの比抵抗值を既述の直角二 等辺三角形による表示法で表示し, 等比 抵抗曲線を求めた図である。地表面が 水 平で均質媒質であれば比抵抗值は単位 1 であり，第 5 図に打いて，0.5 から 1.8 までの変化が現われているのが地形の影 響である。すなわち, 地形の影響は相当 に大きく，山の部分に扔いては高い比抵 抗分布を現わし，その両側飞拈いて多少 低い分布がある。また，谷の部分におい ては低い比抵抗分布を現わし，その両側 飞扣いて多少高い分布がある。山の部分 飞打いては均質構造の約 2 倍の極大值を しめし, 谷の部分に扣いては均質構造の 約 $1 / 2$ 倍の極小值をしめしている。山の 部分に扣いては極大值の範囲は小である が, 谷の部分においては極小值の範囲は 大である。山から谷へ移行する測点番号 -8より 7 までは山と谷つ両方の影響が 現われ比抵抗分布は相当飞複雑になる。

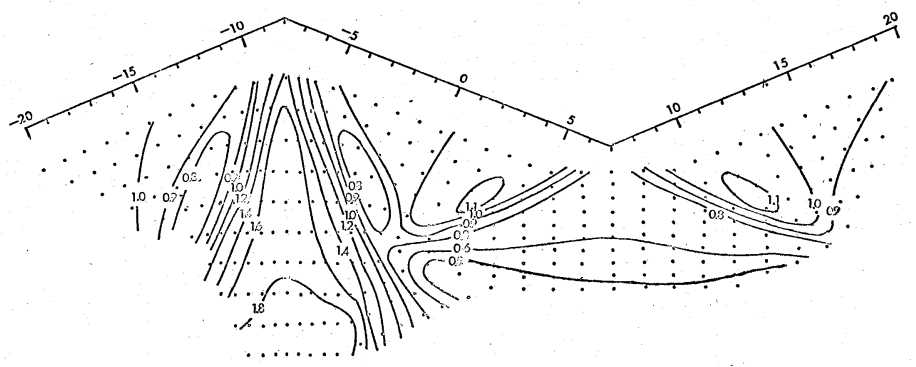

55等比抵抗曲線 $(A(2 / 5)$ B(2/5)0, CCPP, $a=2)$

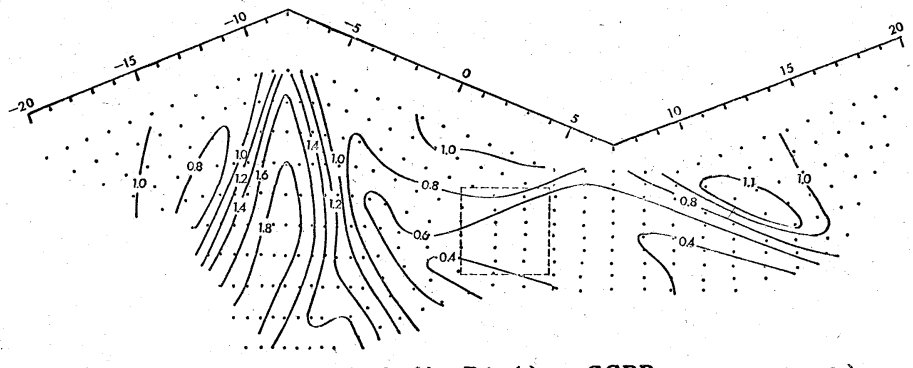

36国等比抵抗曲楾 $\left(\mathrm{A}(2 / 5) \mathrm{B}(2 / 5) 3, \mathrm{CCPP}, a=2, \rho_{1}=0\right)$

構造が, 周波数によって比抵抗の変化を現わす, いわゆ るI.P. 特性を現わす場合には, 周波数効果曲線によっ て地形の影響を除去するような解析ができることである が，この報告では比抵抗による解析までの説明にとどめ た（次の講演題目「電気探査のアナログ計算機によ る結果解釈法」参照)。I.P. 法による探査では現地の 測定精度は従来の比抵抗のみの場合よりも相当に高い精 度が要求される。すなわち, I.P. 法の結果解釈法が従 来の比抵抗の結果解釈法よりるより確実な解釈を目的と しているので当然ではあるが，I.P. 法の基礎となる比 抵抗分布の解釈がまた新しい問題となってきた。

この報告には, 日本鉱業協会 I.P. 研究会の各会社招 よび各大学の援助をえたので, 感謝の意を表する次第で ある。

\title{
4. 結㝘
}

I.P. 法の特長は第 6 図において断面が $4 \times 4$ の地下

1）I.P.研究会報告書 : 日本鉱業協会, 昭和 41 年 12 月

2) I.P. 特集号: 物理探鉱, 19 巻, $4 \cdot 5$ 号, 昭和 41 年 10 月

\section{7 電気探査のアナログ計算機による結果解釈法}

\section{1. 緒言}

金属鉱床の電気扣よび磁気探査の結果解釈は一般に困 難である。理論的にはポテンシャル論の逆境界值問題に なり。簡単な例題の場合でも相当に難解である。鉄鉱床 に対する磁気探査は一般に空気と土地の透磁率が相等し いと考えてょく，目的の鉄鉱床のみの透磁率を解析すれ ばよいので他の金属鉱床の結果解釈よりは容易である。 鉄以外の例えば。銅, 鉛, 亚鉛などの金属鉱床に対して は一般に電気探查法が用いられるが，この場合の物理的 性質は電気の導電率である。空気は絶絯物で導電率は零 であるが, 土地はある值の導電率をもち,さらに目的の 銅, 鉛, 亜鉛などの鉱床もまたある值の導電率をもって いるので、磁気探査に比べて, 境界条件が多くなり結果 解釈がむずかしくなる。ここでは電位を用いる電気探査

$$
\text { 京都大学工学部教授.工博 吉 住 永 三 郎(正会員) }
$$

の結果解釈について説明する。

現在一般に用いられている理論的な結果解釈法として は水平構造に対する方法がある。例えばWenner 電極配 置やSchlumberger 電極配置に対して多くの標準曲線 や解析曲線が発表されている。この解釈法は水平的に首 をなした一般地質構造の解釈に用いられている。地質条 件が水平方向に単純で、各層がある程度の厚さと適当な 導電率をもっていれば結果解釈はかなり正確である。し かし，任意の形状の垂直構造に対する結果解釈法は末だ 確立されていない。この場合，一つの方法としては、鉱 床モデルを考えて, 電位や比抵抗を解析し、いわゆる標 準曲線を数多く求めて扣いて, この標準曲線と現地での 測定結果とを比較検討する方法が採用されている。他の 方法としては, 既知鉱床とその付近の湘定結果とからえ られる測定結果の異常部と既知鉱床との統計的資料を求 


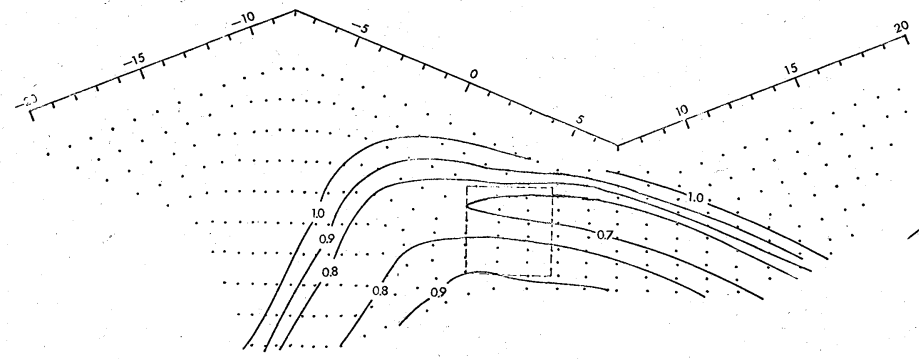

第 1 図 等比抵抗解析曲線 $(\mathrm{A}(2 / 5) \mathrm{B}(2 / 5) 3 / 0, \mathrm{CCPP}, a=2)$

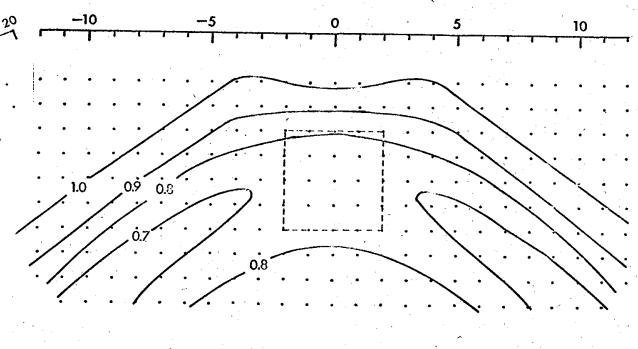

第2图等比抵抗曲線 $\left(\mathrm{C}_{4}\right.$, CCPP, $a=2, \rho_{1}=0$ )
めておいて，この資料と探査すべき現地での測定結果と を比較検討する方法も考元られる。前者は標準曲線によ る，後者は Case Historyによる解釈法であるが，こ の両者はとくに区別する必要はなく, Case History はある意味では標準曲線であり，標準曲線はある意味で は Case History になる。この報告では, 当研究室で 開発したアナログ計算機を用いて結果解釈する方法の概 略を説明する。

\section{2. 結果解 釈 法の概 要}

電気探査の測定結果を解釈する場合には, 地形図, 地 質図扣よび電気探查の測定結果が与えられる。ボーリン グや坑道の操査結果があれば，これらの結果が追加され る。結果解釈の順序としては

(1) 地形の解析

（2）一般地質構造（たとえば断層や表土層など）の解 析

(3) 目的鉱床の解析

\section{となる。}

目的鉱床以外で測定結果に悪い影響を扣よぼすNois e と目的鉱床それ自身による Signalとを分離することが 目的であるが、もちろん理論的な取り扱いは非常に煩雑 であり,アナログ計算機によって解析を行なう。目的鉱 床のみによるSignalが抽出できれば，標準曲線などと 比較して結果解釈は容易になる。この場合，地形はもち ろん既知であり，一般地質構造もできるだけ正確に表現 できれば,これら両者の解析はフナログ計算機を用いて 行ならことができる。

\section{$2 \cdot 1$ 地形の解析}

わが困のように特に地形が複雑な場合には重要である。 例題として,この前の講演「I.P. 研究会で検討された 比抵抗曲線」とい5題目の「3.地形の影響」の第 6 図 （以下この報告の図面は第 6 図（I.P.）と.かく）を説明 する。第 5 図 (I.P.) 地形のみの影響で, 第 6 図 (I. P. ) は地形と地下構造の両者による結果である。簡単な 一つの解析法として第 6 困 (I.P.) の各点の值を第 5 困 （I．P．）の各点の值で割れば，第 1 図の結果をうる。第 1 図と第 6 涩 (I.P.) とを比較すれば等比抵抗曲線は非 常に単純になっている。第 2 図は地表面が水平な場合の,
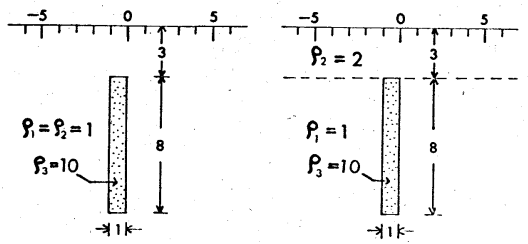

( 51$)$

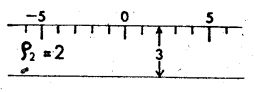

$\rho_{1}=\rho_{3}=1$

S 3 )
第 6 図( I.P.) と同様の地下構造が存在する場合の等比 抵抗曲線の標準曲線であり, 両者の比較検討が容易にな

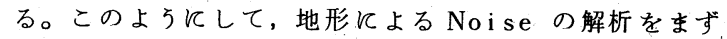
行な5(第 1 図はI.P. 法に扣ける等周波数効果曲線と 同一傾向の曲線である)。

\section{$2 \cdot 2$ 一般地質構造の解析}

地質構造が複雑であれば測定結果の解釈は当然むずか しくなるが、地質構造の一部分でも，ある程度明確であ ればこれによるNoi se の解析を行なえば目的鉱床の解 析が簡単になる。例えば, 表土層の Noi se 亿ついて説 明する。第 3 図(b)は表土層が存在し、その下に垂直構造 がある場合である。CCPP の電極配置で電極間隔 $\boldsymbol{a}$ $a=2$ とし, 隔離係数 $n$ を $n=1,2,4,6$ 打よび 8 と したときの等比抵抗曲線が第 4 図である。第 5 図は第 3 図(a)の表土首がない場合の垂直構造のみによる等比抵抗 曲線である。第 4 図と第 5 図とを比較すると, 地形の場 合に扣ける第 6 図 (I.P.) と第 5 図 (I.P.) と同様に, 目的鉱床からの Signalが表土層の Noi se で影響され ている。この場合の例題は表土層が水平でもっとも簡単 な例であるが，これに断層などが存在すると測定結果は 相当に複雑になる。この場合，表土層のみの第 3 図(c)の 等比抵抗曲線は水平な線になるので省略するが, 地形の 場合と同様，簡単な一つの解析法として，第 4 図の各点 の值を第 3 図(c)でえられる各点の值で割れば, 第 6 図の 結果を 5 る。第 6 図と表土層と垂直構造が存在する第 4

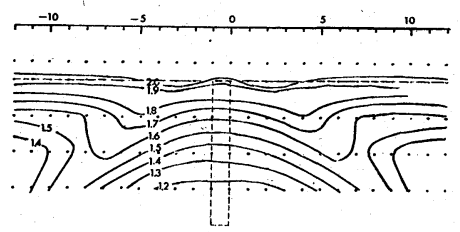

第 4 图 等比抵抗曲線 (S2, CCPP, $a=2)$

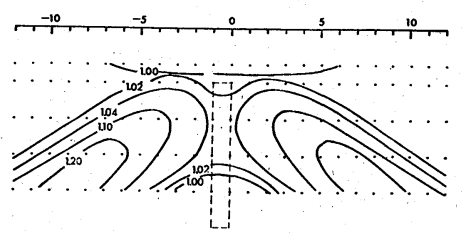

第5国等比抵抗解析曲線 ( S 2/3, CCPP, $a=2$ )

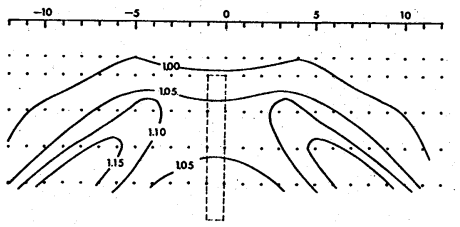

第6図、等比抵抗曲線 $(\mathrm{S} 1, \mathrm{CCPP}, a=2)$ 
図とを比較すると、等比抵抗曲線の傾向は異なったもの になり，第 6 図は垂直構造のみが存在する第 5 図の標準 曲線と傾向が似て，両者の比較検討が容易になる。この ようにして，一般地下構造によるNoise の解析をでき るだけ正確に行なら。

次飞, (3)目的鉱床の解析になるが, 地形扣よび一般地 質棈造の解析が終りな打測定結果に異常部があれば，標 準曲線や Case Hi s t ory 几よる資料を参照して結果解 釈を行なう。また,さらにアナログ計算機によって解析 を進める。その間に, 現地の地質構造の情報がえられれ ばもちろん加味しながら解析が進められることになる。

\section{3. 結}

現在, 住友金属鉱山株式会社, 日鉄鉱業株式会社や日 本鉱業協会の I.P. 研究会と共同して行なっている課題 は探查地区の (1) 地形の解析々当該探査地区 (2) 一般地 質構造のモデルの標準曲線の解析である。今後, これら の一般地質構造のモデルの標準曲線などとともにCa e Historyなどの発表ができることになれば幸いと思っている。 この報告には住友, 日鉄打上び鉱業協会のI.P. 研究 会の各会社打よび各大学の援助をえたので, 感謝の意を 表する次第である。 